\title{
KOMPOSISI DAN DISTRIBUSI SPASIAL LARVA IKAN EKONOMIS PENTING DI PERAIRAN ESTUARI BANJIR KANAL TIMUR KOTA SEMARANG
}

\author{
The Composition and Spatial Distribution of Economically Important Fish Larvae \\ in Estuarie of Eastern Banjir Kanal Semarang \\ Daryumi, Sahala Hutabarat*), Abdul Ghofar \\ Program Studi Manajemen Sumberdaya Perairan, Departemen Sumberdaya Akuatik \\ Fakultas Perikanan dan Ilmu Kelautan, Universitas Diponegoro \\ Jl. Prof. Soedarto, SH, Tembalang, Semarang. Jawa Tengah - 50275, Telp/Fax. +6224 7474698 \\ Email : Daryumi94@gmail.com
}

\begin{abstract}
ABSTRAK
Perairan estuari Banjir Kanal Timur berfungsi sebagai daerah asuhan bagi larva ikan. Daerah estuari bersifat fluktuatif sehingga sifat-sifat fisik, kimia dan biologi bervariasi, pada fase larva ikan sangat menentukan kelangsungan hidup dari spesies ikan maupun populasi. Oleh karena itu, mengetahui keberadaan larva ikan ekonomis penting dapat memberi informasi tentang daerah mana yang dapat digunakan sebagai daerah penangkapan dan daerah mana yang harus dilestarikan. Penelitian dilakukan pada bulan Maret-April 2016 di Muara Banjir Kanal Timur Kota Semarang yang bertujuan untuk mengetahui komposisi dan distribusi spasial larva ikan. Metode yang digunakan yaitu metode Purposive Random Sampling. Hasil penelitian menunjukan jumlah rata-rata larva ikan sebanyak 1851 ind $/ 150 \mathrm{~m}^{3}$ terdiri dari famili Apogonidae, Mugilidae, Gerreidae, Lutjanidae, Engraulidae, Nemipteridae, Ambassidae, Gobiidae dan Chanidae. Jenis larva ikan yang yang paling banyak ditemukan adalah Mugillidae (Belanak) 38,92\%, sedangkan yang paling sedikit adalah Chanidae (Bandeng) 0,38\%. Larva ikan paling banyak tertangkap di daerah pantai (Titik III) dan yang paling sedikit tertangkap didaerah muara menuju sungai (Titik VI). Perhitungan indeks morista menunjukan larva ikan menyebar secara acak. Struktur komunitas larva ikan yaitu indeks keanekaragaman (H') berkisar 0,64-1,66, indeks keseragaman (E) berkisar 0,14-0,39, dan indeks dominasi berkisar 0,21-0,67. Berdasarkan hasil uji regresi menunjukkan antara salinitas dengan kelimpahan larva ikan berkorelasi positif, sedangkan kecepatan arus dengan kelimpahan larva ikan berkorelasi negatif.
\end{abstract}

Kata Kunci: Estuari; Larva Ikan; Komposisi; Distribusi; Banjir Kanal Timur Semarang.

\section{ABSTRACT}

The estuaries of eastern Banjir Kanal served as the nursery ground for fish larvae. Areas of estuaries were fluctuating. So the parameters of the physical, chemical and biological were variation, in fish larvae phas largely determine survival rate of fish species or populations. For it to, knowing the existence of economically important fish larvae could providing information about which areas be using as a capture area and which areas that should be preserved. Research conducted in March-April 2016 at the Eastern Banjir Kanal of Semarang, aims to find out the composition and spatial distribution of fish larvae. The method used Purposive Random Sampling method. The research showed the range number of larvae as 1851 ind/150m ${ }^{3}$ consists of Familia Apogonidae, Mugilidae, Gerreidae, Lutjanidae, Engraulidae, Gobiidae, Ambassidae, Nemipteridae and Chanidae. Types of fish larvae found the most high was Mugillidae (Mullet) 38,92\%, while the least was Chanidae (Milkfish) 0,38\%. The larvae of most fish caught in coastal areas (point III) and the least caught in the estuary towards the river (Point VI). The calculation of the index morista fish larvae spread randomly. Fish larvae community structures were the index of diversity $\left(H{ }^{\prime}\right)$ range from 0,64-1,66, uniformity index (E) range 0,14-0,39, and dominance index range from 0,21-0,67. Based on the results of the regression analysis showed between salinity with an abundance of fish larvae correlating positively, where the current speed with an abundance of fish larvae correlating negatively.

Keywords: Estuarie; Fish Larvae; Composition; Distribution; Eastern Banjir Kanal Semarang.

*) Penulis Penanggungjawab

() Copyright by Management of Aquatic Resources (MAQUARES) 


\section{PENDAhuluan}

Perairan esturia Banjir Kanal Timur Kota Semarang merupakan daerah muara dari sistem sungai Banjir Kanal Timur, Tambak Lorok (Kali Banger) dan Kali Tenggang. Sungai Banjir Kanal Timur melintasi Kota Semarang bagian timur yang padat pemukiman. Sungai Banjir Kanal Timur memiliki panjang 14,25 km dengan debit rata-rata 295,33 liter/detik (Wulandari, 2012). Disekitar daerah muara terdapat perikanan budidaya tambak, pelabuhan, pembangkit listrik tenaga uap, penangkapan ikan menggunakan lift net dan pancing, dan pembuangan limbah.

Larva ikan merupakan fase awal dari pertumbuhan ikan (Subiyanto et al., 2008). Fase ini sangat menentukan kelangsungan hidup dari satu spesies ikan maupun populasi ikan tersebut. Oleh karena itu mengetahui distribusi larva ikan sangat penting terhadap implikasi penilaian kelimpahannya. Diharapkan dengan memahami proses ekologis larva ikan akan dapat memberi arahan yang jelas tentang keberadaan larva ikan, sehingga dengan demikian dapat memberi informasi tentang daerah mana yang dapat digunakan sebagai penangkapan dan daerah mana yang perlu dijaga kelestariannya.

Sampai saat ini penelitian tentang distribusi larva ikan pada berbagai habitat vital di kawasan pantai utara jawa masih sangat sedikit. Demikian pula informasi tentang keberadaan larva ikan ekonomis penting khususnya di perairan Banjir Kanal Timur. Informasi ini sangatlah penting untuk mengetahui distribusi larva ikan yang berkaitan dengan daerah asuhannya. Mengingat pentingnya informasi tentang keberadaan larva ikan ekonomis penting sebagai dasar dalam usaha pengelolaan sumberdaya perikanan di perairan estuari Banjir Kanal Timur.

\section{MATERI DAN METODE PENELITIA}

Penelitian ini dilakukan di Perairan Banjir Kanal Timur Kota Semarang. Pengambilan sampel dilakukan pada 6 titik yaitu 3 titik di muara ke arah sungai dan 3 titik di muara ke arah laut (Gambar 1). Pengambilan sampel dilakukan satu minggu sekali dari 13-27 Maret 2016 dengan menggunakan seine net panjang $2 \mathrm{~m}$ lebar $1 \mathrm{~m}$ dan mesh size $1 \mathrm{~mm}$. seine net dioperasikan dengan cara ditarik sejauh $50 \mathrm{~m}$ sejajar dengan pantai atau muara. Sampel ikan yang tertangkap selanjutnya dimasukkan ke botol yang telah berisi formalin $4 \%$ dan dibawa ke laboratorium untuk diidentifikasi sampai dengan tingkatan famili. Selama pengambilan sampel dilakukan pula pengukuran parameter fisika-kimia perairan seperti suhu, salinitas, kecerahan, kedalaman, $\mathrm{pH}$, dan kecepatan arus.

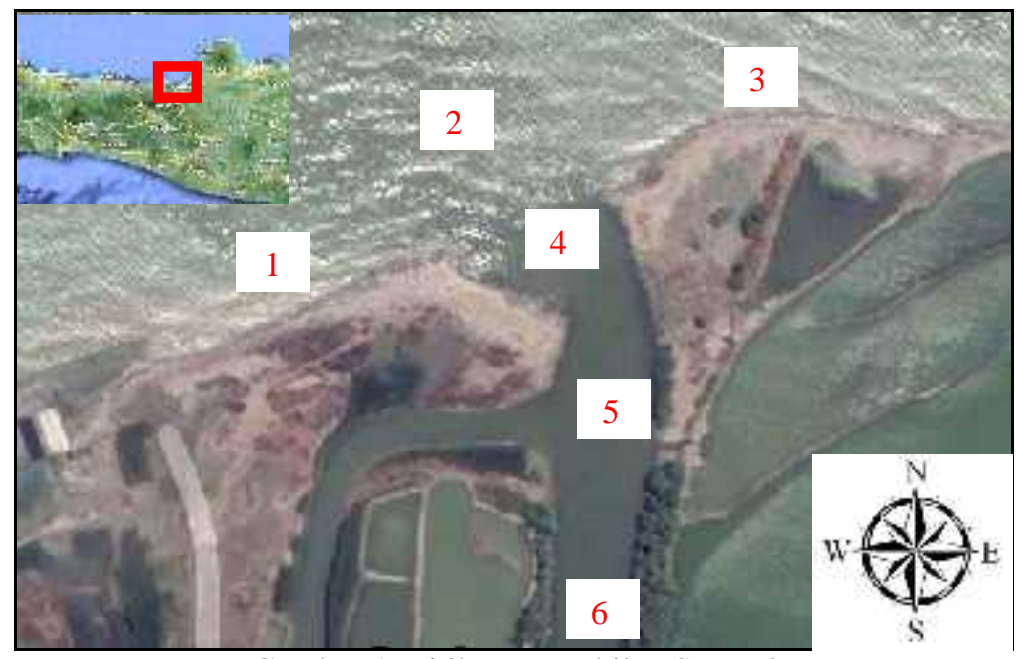

Gambar 1. Titik Pengambilan Sampel

Data larva ikan yang tertangkap dianalisis dengan indeks morista, kelimpahan, indeks keanekaragam $\left(\mathrm{H}^{\prime}\right)$ shanonon-wiener (Anwar, 2008), indeks keseragaman (E) (Basmi, 1999) dan indeks dominasi (D) Simpson (Anwar, 2008). Untuk melihat keterkaitan antara kelimpahan dengan salinitas dan kecepatan arus digunakan analisis regresi linier (Steel and Storrie 1980 dalam Anwar (2008).

\section{HASIL DAN PEMBAHASAN \\ Komposisi Larva Ikan}

Jumlah rata-rata larva ikan yang tertangkap di Perairan estuari Banjir Kanal Timur sebanyak 1851 ind $/ 150 \mathrm{~m}^{3}$ yang terdiri dari 9 famili yaitu Apogonidae, Mugillidae, Gerreidae, Lutjanidae, Engraulidae, Nemipteridae, Ambassidae, Gobiidae, dan Chanidae (Tabel 1). Famili yang ditemukan dengan jumlah rata-rata paling tinggi adalah Mugillidae sebanyak 720 ind $/ \mathrm{m}^{3}$ dengan presetase 38,92\%. Hal ini dikarenakan ikan Mugillidae hidup didaerah perairan dangkal seperti pantai dan muara. Menurut Rahmatin et al. (2010) ikan belanak (Mugil cephalus) tersebar luas di seluruh dunia mulai dari $42^{\circ} \mathrm{LS}-42^{\circ} \mathrm{LU}$, yang meliputi daerah estuaria intertidal, perairan tawar maupun perairan pantai.

\footnotetext{
${ }^{\complement}$ Copyright by Management of Aquatic Resources (MAQUARES)
} 
Larva ikan chanidae yang lebih dikenal dengan ikan bandeng tertangkap paling sedikit hanya rata-rata 7 ind $/ 150 \mathrm{~m}^{3}$ dengan presentase $0,38 \%$. Hal ini diduga menurunnya stok ikan dewasa dari famili Chanidae yang diakibatkan oleh pengambilan benih ikan (nener) dari alam untuk dibudidayakan.

Tabel 1. Komposisi Jenis dan Jumlah Larva Ikan (ind/150m³) yang Tertangkap Tiap Pengambilan Sampel

\begin{tabular}{rlrrrrrrr}
\hline \multirow{2}{*}{ No. } & \multirow{2}{*}{ Famili } & \multicolumn{3}{c}{ Pengambilan Sampel ke- } & Jumlah & Rata-rata & $\begin{array}{c}\text { Presentase } \\
\text { (\%) }\end{array}$ \\
\cline { 3 - 6 } & & \multicolumn{1}{c}{ I } & \multicolumn{1}{c}{ II } & III & & & \\
\hline 1. & Apogonidae & 8 & 14 & 12 & 34 & 11 & 0.61 \\
2. & Mugillidae & 698 & 672 & 791 & 2161 & 720 & 38.92 \\
3. & Gerreidae & 316 & 386 & 360 & 1062 & 354 & 19.13 \\
4. & Lutjanidae & 156 & 285 & 227 & 668 & 223 & 12.03 \\
5. & Engraulidae & 48 & 29 & 46 & 123 & 41 & 2.22 \\
6. & Nemipteridae & 383 & 342 & 373 & 1098 & 366 & 19.78 \\
7. & Ambassidae & 64 & 73 & 82 & 219 & 73 & 3.94 \\
8. & Gobiidae & 61 & 38 & 37 & 166 & 55 & 2.99 \\
9. & Chanidae & 8 & 8 & 5 & 21 & 7 & 0.38 \\
& Jumlah & 1742 & 1847 & 1933 & 5552 & 1851 & 100 \\
\hline
\end{tabular}

Sumber: Penelitian 2016

\section{Distribusi Larva Ikan}

Pada Gambar 2 terlihat bahwa istribusi larva ikan yang tertangkap dengan jumlah individu yang cukup banyak dijumpai di titik I dan III yang merupakan daerah pantai, titik IV dan V yang merupakan daerah muara sungai. Larva ikan yang ditemukan dalam jumlah sedikit ditemukan pada titik II dan IV yang merupakan daerah pintu masuknya air laut ke sungai atau sebaliknya.

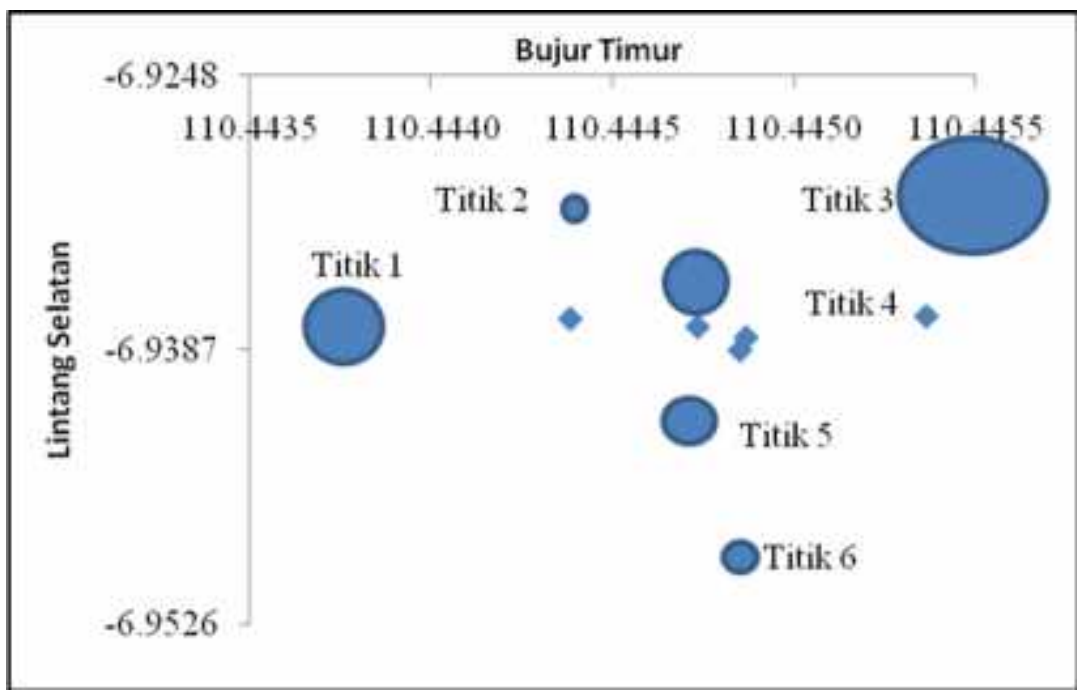

Keterangan :

Titik $1=72 \mathrm{Ind} / 150 \mathrm{~m}^{3}$

Titik $2=97 \mathrm{Ind} / 150 \mathrm{~m}^{3}$

Titik $3=191 \mathrm{Ind} / 150 \mathrm{~m}^{3}$

Titik $4=293 \mathrm{Ind} / 150 \mathrm{~m}^{3}$

Titik $5=325 \mathrm{Ind} / 150 \mathrm{~m}^{3}$

Titik $6=872 \mathrm{Ind} / 150 \mathrm{~m}^{3}$

Gambar 2. Distribusi Spasial Larva Ikan yang Tertangkap di Perairan Estuari Banjir Kanal Timur

Kelimpahan larva ikan tertinggi ditemukan di titik III rata-rata $872 \mathrm{ind} / 150 \mathrm{~m}^{3}$. Daerah ini merupakan daerah pantai yang memiliki salinitas $28 \%$ (Tabel 3) dengan arus yang tenang, sangat cocok utnuk kehidupan dan perkembangan larva ikan. Selain itu, daerah ini juga menyediakan oksigen sebesar $6,27 \mathrm{mg} / \mathrm{l}$ dan memiliki suhu rata-rata $32,33^{\circ}$. Menurut Simanjuntak (2009), kisaran nilai parameter fisika dan kimia perairan yang baik untuk kehidupan ikan adalah kadar oksigen 3,81-6,33 mg/l, pH 6-8,5, salinitas 17-30\% $\%$ dan suhu 27-33 ${ }^{\circ}$.

Kelimpahan larva ikan terendah di temukan di titik II hanya 72 ind $/ 150 \mathrm{~m}^{3}$. Hal ini disebabkan oleh kecepatan arus yang tinggi, pada fase larva ikan hidup mengikuti arus atau bersifat planktonis. Arus yang deras dapat mengakibatkan larva ikan stress karena belum memiliki alat gerak yang sempurna. Menurut Romimohtarto dan Juawa (2001) kemampuan larva ikan untuk bertahan hidup dalam ligkungan dengan berenang terbatas, sehigga larva ikan lebih merupakan fungsi dari arus daripada distribusi ikan dewasa. 
Pola penyebaran biota dipengaruhi oleh tipe habitat yang meliputi parameter fisika kimia perairan serta makanan dan kemampuan adaptasi dari suatu biota dalam suatu ekosistem (Alfitriatussulus, 2003). Berdasarkan analisis indeks morista, pola distribusi larva ikan di perairan estuari Banjir Kanal Timur menyebar secara acak.

Menurut Zaenudin (2013) pola penyebara acak berarti bahwa tingkat kelangsungan hidup ikan pada saat stadia larva rendah, hal ini dibuktikan dengan sedikit ditemukannya jenis ikan saat stadia larva di daerah muara ke arah sungai. penyebaran bersifat acak berarti keberadaan spesies tidak memiliki kecenderungan untuk hidup berkoloni dan dapat bertahan hidup di mana saja pada suatu ekosistem. pola penyebaran acak juga terjadi karena adanya persaingan yang positif antar individu, sehingga akan mendorong terbentuknya pembagian ruang diantara individu-individu tersebut.

\section{Struktur Komunitas}

Keanekaragaman (H'), keseragaman (E), dan dominansi (D) jenis merupakan kajian indeks yang sering digunakan untuk menduga kondisi suatu lingkungan perairan berdasakan komponen biologis. Kondisi lingkungan suatu perairan dikatakan baik bila diperoleh nilai indeks keanekaragaman (H') dan keseragaman (E) yang tinggi, serta indeks dominansi (D) yang rendah (Hukom, 1999). Nilai masing-masing indeks tersaji di Tabel 2.

Tabel 2. Struktur Komunitas Larva Ikan di Perairan Estuari Banjir Kanal Timur

\begin{tabular}{|c|c|c|c|c|c|c|c|}
\hline \multirow{2}{*}{ No. } & \multirow{2}{*}{ Struktur Komunitas } & \multicolumn{6}{|c|}{ Titik Pengambilan Sampel } \\
\hline & & $\mathbf{I}$ & II & III & IV & $\mathbf{V}$ & VI \\
\hline 1 & Jumlah spesies & 6 & 6 & 8 & 5 & 7 & 4 \\
\hline 2 & Jumlah individu & 325 & 72 & 870 & 293 & 191 & 97 \\
\hline 3 & Indeks Keanekaragaman & 1.49 & 1.66 & 1.57 & 1.47 & 1.53 & 0.64 \\
\hline 4 & Indeks Keseragaman & 0.24 & 0.39 & 0.22 & 0.25 & 0.27 & 0.14 \\
\hline 5 & Indeks Dominasi & 0.26 & 0.21 & 0.27 & 0.26 & 0.25 & 0.67 \\
\hline
\end{tabular}

Sumber: Penelitian 2016

a. Keanekaragaman

Nilai indeks keanekaragaman di titik I, II, III, IV, dan V tergolong dalam tingkat sedang yaitu antara 1-3. Nilai indeks keanekaragaman rendah di titik VI yaitu 0,64 atau kurang dari 1. Hal ini disebabkan oleh rendahnya salinitas, sehingga hanya jenis ikan tertentu yang mampu bertahan hidup. Menurut Zaenudin (2013) nilai keanekaragaman yang kecil disebabkan oleh bebrapa hal, salah satunya fluktuasi kadar salinitas yang besar di perairan muara sungai, sehingga menyebabkan kegagalan berbagai spesies larva yang mampu bertahan hidup di lokasi seperti ini.

Nilai indeks keanekaragaman tergantung dari variasi jumlah spesies dan jumlah individu tiap spesies yang diperoleh, sehingga semakin kecil jumlah spesies dan variasi jumlah individu tiap spesies atau ada beberapa individu yang jumlahnya lebih besar maka keanekaragaman suatu ekosistem akan mengecil. Apabila jumlah spesies dan variasi jumlah individu tiap spesies relatif kecil, hal ini menunjukan bahwa ketidakseimbangan ekosistem yang disebabkan gangguan atau tekanan lingkungan, hal ini berarti hanya jenis tertentu saja yang dapat bertahan hidup (Risawati, 2002).

b. Keseragaman

Nilai indeks keseragaman di Perairan Estuari Banjir Kanal Timur di semua lokasi pengambilan sampel mendekati 0 (nol). Nilai tersebut tergolong dalam nilai yang rendah. Menurut Basmi (1999), bila indeks ini mendekati 0 (nol) maka keseragaman antar spesies di dalam komunitas larva rendah, yang menggambarkan kekayaan individu yang dimiliki masing-masing spesies sangat jauh berbeda.

Hal ini diperkuat oleh Pirzan et al., (2008) yang menyatakan bahwa semakin besar nilai keseragaman dapat dikatakan merata atau jumlah individu dalam spesies relatif sama, sedangkan keseragaman yang bernilai kecil menggambarkan keseragaman antar spesies di dalam komunitas rendah, yang berarti kekayaan individu yang dimiliki masing-masing spesies sangat jauh berbeda.

c. Dominasi

Nilai indeks dominasi digunakan untuk mengetahui ada-tidaknya jenis larva ikan tertentu yang mendominasi suati ekosistem. Nilai indeks dominasi di titik I, II, III, IV, dan V yaitu mendekati 0 (nol), Hal ini berarti pada titik tersebut terdapat dominasi oleh satu famili. Sedangkan pada titik VI nilai indeks dominasi mendekati 1 maka pada titik ini tidak ada famili yang mendominasi.

Jenis larva ikan yang ditemukan ada yang lebih mendominasi dari jenis lainnya. Hal ini dikarenakan perbedaan habitat, dimana lokasi di muara sungai memiliki salinitas yang berfluktuatif, persaingan untuk mencari makan juga semakin besar, sehingga hanya jenis-jenis tertentu saja yang dapat bertahan pada kondisi lingkungan seperti ini. 


\section{Parameter Fisika dan Kimia Lingkungan}

Pengukuran parameter fisika dan kimia lingkungan meliputi suhu, salinitas, kecepatan arus, kecerahan, kedalaman, pH, Kadar Oksigen. Hasil pengukuran tersaji di Tabel 3.

Tabel 3. Hasil Rata-rata 3 Kali Pengulangan dari Pengukuran Variabel Kualitas Perairan

\begin{tabular}{|c|c|c|c|c|c|c|c|c|}
\hline \multirow[b]{2}{*}{ No } & \multirow[b]{2}{*}{ Parameter } & \multirow[b]{2}{*}{ Satuan } & \multicolumn{6}{|c|}{ Rata-rata Nilai } \\
\hline & & & $\begin{array}{c}\text { Titik } \\
\text { I }\end{array}$ & $\begin{array}{c}\text { Titik } \\
\text { II }\end{array}$ & $\begin{array}{c}\text { Titik } \\
\text { III }\end{array}$ & $\begin{array}{c}\text { Titik } \\
\text { IV }\end{array}$ & $\begin{array}{c}\text { Titik } \\
\text { V }\end{array}$ & $\begin{array}{c}\text { Titik } \\
\text { VI }\end{array}$ \\
\hline 1 & Suhu & ${ }^{0} \mathrm{C}$ & 32.67 & 32.33 & 32.33 & 31 & 31.33 & 31 \\
\hline 2 & Salinitas & $\%$ & 22 & 20 & 28 & 16 & 11 & 8 \\
\hline 3 & Kecepatan Arus & $\mathrm{m} / \mathrm{s}$ & 0.07 & 0.25 & 0.05 & 0.15 & 0.13 & 0.15 \\
\hline 4 & Kecerahan & $\mathrm{Cm}$ & 36.83 & 32.17 & 29.17 & 29 & 29.33 & 29.5 \\
\hline 5 & Kedalaman & $\mathrm{Cm}$ & 93 & 61.33 & 94.33 & 75 & 77.33 & 72 \\
\hline 6 & $\mathrm{pH}$ & - & 6 & 6 & 6 & 6 & 6 & 6 \\
\hline 7 & Kadar Oksigen & $\mathrm{mg} / \mathrm{ltr}$ & 8.24 & 5.20 & 6.27 & 5.57 & 4.91 & 3.87 \\
\hline
\end{tabular}

\section{Hubungan Salinitas dan Kecepatan Arus dengan Kelimpahan Larva Ikan}

a. Hubungan salinitas dengan kelimpahan larva ikan

Hubungan salinitas dengan kelimpahan larva ikan pada perairan esrtuari Banjir Kanal Timur tersaji di Gambar 3.

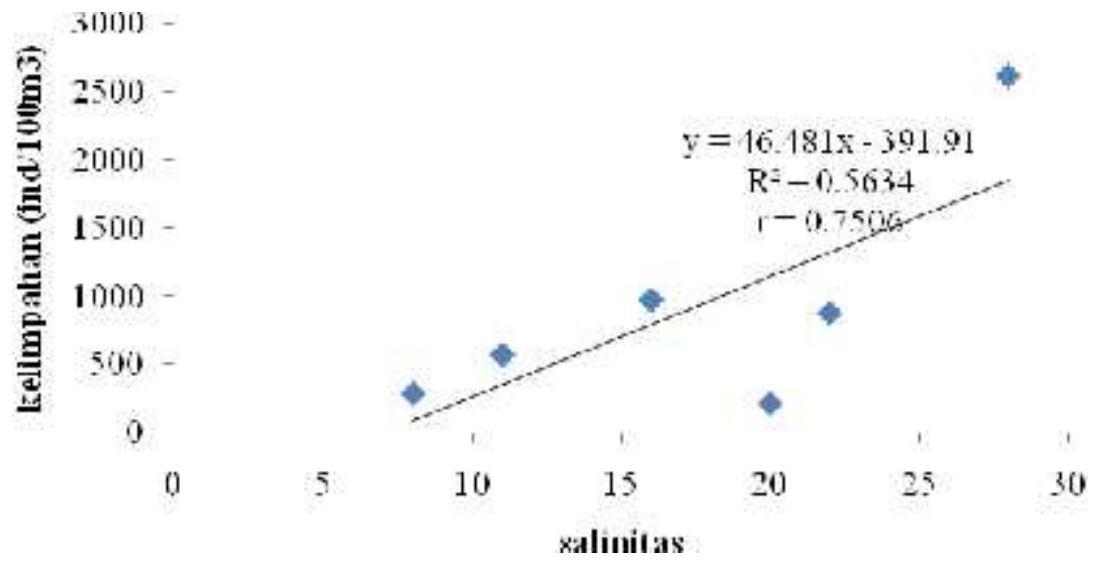

Gambar 3. Grafik Hubungan Salinitas dengan Kelimpahan Larva Ikan

Pada Muara Sungai Banjir Kanal Timur.

Berdasarkan hasil analisis regresi linier antara faktor kelimpahan dengan faktor lingkungan, faktor salinitas memiliki nilai koefisien determinasi dan koefisien korelasi yang lebih besar $(>0.5)$ dibandingkan dengan kecepatan arus. Hal ini berarti bahwa, dari segi nilai koefisien determinasi $\left(\mathrm{R}^{2}\right)$ dan korelasi (r) yang besar, salinitas memiliki peranan penting terhadap kelimpahan larva dan juvenil ikan.

Selain itu, faktor salinitas juga memiliki nilai korelatif positif terhadap kelimpahan larva ikan. Artinya, semakin tinggi nilai salinitas akan menyebabkan kelimpahan larva ikan semakin tinggi, begitu pula sebaliknya, apabila nilai salinitas semakin rendah akan menyebabkan kelimpahan larva ikan rendah. Menurut Sentosa dan Yayuk (2011), salinitas memiliki hubungan yang sinergis ( $r>0.5)$ dengan kelimpahan larva ikan.

b. Hubungan kecepatan arus dengan kelimpahan larva ikan

Hubungan kecepatan arus dengan kelimpahan larva ikan pada perairan esrtuari Banjir Kanal Timur tersaji di Gambar 4. Faktor kecepatan arus memiliki nilai korelatif negatif terhadap kelimpahan larva ikan. Artinya, semakin tinggi nilai kecepatan arus akan menyebabkan kelimpahan larva ikan semakin rendah, begitu pula sebaliknya, apabila nilai kecepatan arus semakin rendah akan menyebabkan kelimpahan larva ikan tinggi. Menurut Adi (2007), hubungan korelasi negatif antara arus dan kelimpahan larva dan juvenil ikan berarti setiap penurunan arus perairan maka kelimpahan individu serta spesies larva dan juvenil ikan akan bertambah. Menurut Romimohtarto dan Juwana (2001), kemampuan larva untuk bertahan hidup dalam lingkungan dengan berenang terbatas, sehingga distribusi larva lebih merupakan fungsi dari arus daripada distribusi ikan dewasa. 


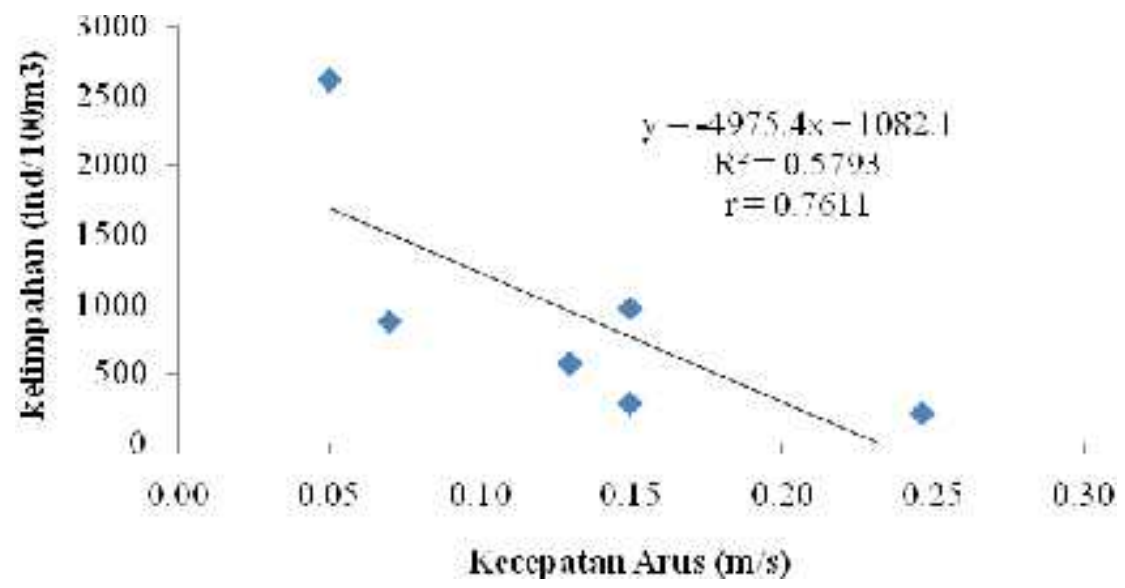

Gambar 4. Grafik Hubungan Kecepatan Arus dengan Kelimpahan Larva Ikan Pada Muara Sungai Banjir Kanal Timur.

Secara keseluruhan kelimpahan larva ikan sangat dipengaruhi oleh faktor fisika-kimia perairan. Hal ini disebabkan karena adanya dinamika transport dari larva ikan itu sendiri yang dipengaruhi oleh faktor fisika kimia seperti salinitas dan kecepatan arus. Akibatnya kelimpahan larva ikan akan berbeda disetiap lokasi sesuai dengan kondisi perairan itu sendiri.

\section{Rekomendasi Pengelolaan}

Pengelolaan sumberdaya ikan adalah suatu proses yang terintegrasi mulai dari pengumpulan informasi, analisis, perencanaan, konsultasi, pengambilan keputusan, alokasi sumber dan implementasinya, dalam rangka menjamin kelangsungan produktivitas serta pencapaian tujuan pengelolaan (FAO, 1997 dalam Suyasa, 2003). Sementara Widodo dan Nurhakim (2002) mengemukakan bahwa secara umum, tujuan utama pengelolaan sumberdaya ikan adalah untuk menjaga kelestarian produksi, terutama melalui berbagai regulasi serta tindakan perbaikan (enhancement), meningkatkan kesejahteraan ekonomi dan sosial para nelayan, serta memenuhi keperluan industri yang memanfaatkan produksi tersebut.

Rekomendasi yang dapat penulis berikan terhadap pengelolaan sumberdaya perikanan terutama di daerah perairan esturi Banjir Kanal Timur Kota Semarang yaitu pemerintah setempat harus memiliki kebijakankebijakan dan bertindak lebih tegas terhadap masyarakat yang sering melakukan penangkapan ikan-ikan kecil di sekitar pantai maupun muara sungai. Selain itu kebijakan terhadap pembuangan sampah oleh para penduduk dibantaran Sungai Banjir Kanal Timur perlu diterapkan karena dikhawatirkan apabila sampah terus-menerus dibuang ke sungai maka berpotensi pencemaran lingkungan.

Hal tersebut dilakukan, supaya keberlangsungan dari individu-individu ikan pada stadia larva tetap terjaga, sehingga sumberdaya perikanan di Semarang dapat terus lestari. Keberlanjutan sumberdaya ikan yang lestari sangat ditentukan dengan keberlangsungan hidup ikan pada stadia larva, hal ini dikarenakan pada stadia tersebut, kehidupan ikan sangat rentan terhadap berbagai faktor. Faktor yang mempengaruhi keberlangsungan sumberdaya ikan itu sendiri antara lain, predator, ketersediaan makanan, dan juga perubahan lingkungan di alam.

\section{KESIMPULAN}

Kesimpulan yang dapat diambil dari penelitian ini adalah sebagai berikut:

1. Jenis larva ikan yang ditemukan selama penelitian di perairan estuarI Banjir Kanal Timur Kota Semarang berjumlah 2529 individu terdiri dari 9 famili yang teridentifikasi yaitu Apogonidae, Mugillidae, Gerreidae, Lutjanidae, Engraulidae, Nemipteridae, Ambassidae, Gobiidae dan Chanidae. Larva ikan Mugillidae (Belanak) paling melimpah dengan jumlah 1005 individu karena muara dan pantai sesuai dengan habitat ikan belanak. Larva ikan Chanidae (Bandeng) paling sedikit hanya 8 individu, karena larva ikan bandeng (nener) di alam sering ditangkap untuk dibudidayakan di tambak.

2. Distribusi larva ikan yang tertangkap di Perairan Estuari Banjir Kanal Timur Kota Semarang dengan jumlah cukup besar dijumpai di daerah pantai (titik I dan III) dan daerah muara (titik VI dan V), sedangkan di daerah tepat di pintu masuk air laut ke sungai (titik II) dan daerah sungai (titik VI) sedikit larva ikan yang tertangkap. Pola penyebaran larva ikan berdasarkan indeks morista menyebar secara acak. 


\section{UCAPAN TERIMA KASIH}

Terima kasih penulis ucapkan kepada semua pihak yang telah membantu mulai dari persiapan penelitian, terlaksananya penelitian sampai selesai.

\section{DAFTAR PUSTAKA}

Adi W. 2007. Komposisi dan Kelimpahan Larva dan Juvenil Ikan yang Berasosiasi dengan Tingkat Kerapatan Lamun yang Berbeda di Pulau Panjang Jepara. Jurnal Sumberdaya Perikanan Vol. 1 ISSN 1978 -1652.

Alfitriatussulus. 2003. Sebaran moluska (bivalvia dan gastropoda) di muara sungai Cimandiri, Teluk pelabuhan Ratu, Sukabumi, Jawa Barat [skripsi]. Program Studi Manajemen Sumberdaya Perairan, Fakultas Perikanan dan Ilmu Kelautan, Intitut Pertanian Bogor.

Anwar N. 2008. Karakteristik fisika kimia perairan dan kaitannya dengan distribusi serta kelimpahan larva ikan di Teluk Palabuhanratu [Tesis]. Sekolah Pascasarjana, Institut Pertanian Bogor.

Basmi J. 1999. Planktonologi: Plankton sebagai bioindikator kulaitas air. Departemen Manajemen Sumberdaya Perairan. Fakutas Perikanan dan Ilmu Kelautan. Insttitut Pertanian Bogor.

Hukom, FD. 1999. Ekostruktur dan distribusi spasial ikan karang (famili Labridae) di perairan Teluk Ambon. Pros. Lok. Pengelolaan dan Iptek Terumbu Karang Indonesia. Jakarta.

Pirzan AM dan PR Pong-Masak. 2008. Hubungan keragaman fitoplankton dengan kualitas air di Pulau Baulung, Kabupaten Takalar, Sulawesi Selatan. Biodiversitas. Vol. 9 (3): 217-221. Maros: Balai Riset Perikanan Budidaya Air Payau.

Rahmatin A, Nurlita A, Aunurohim dan Dewi H. 2010. Studi Variasi Morfometri Ikan Belanak (Mugil cepalus) di Muara Aloo Sidoarjo dan Muara Wonorejo Surabaya. Isntitut Teknologi Sepuluh Nopember. Surabaya.

Risawati, D. 2002. Struktur komunitas moluska(Gastropoda dan Bivalvia) serta asosiasinya pada ekosistem Mangrove Kawasan Muara Sungai Bengawan Solo. Ujung Pangkah Gresik, Jawa Timur. (Skripsi) FPIK IPB. Bogor.

Romimohtarto K dan S. Juwana. 2001. Biologi Laut Ilmu Pengetahuan Tentang Biota Laut. Djambatan. Jakarta.

Sentosa AA dan Yayuk S. 2011. Sebaran Kelimpahan Meroplankton di Muara Sungai Poso Sulawesi Tengah. Prosiding Forum Nasional Pemacuan Sumber Daya Ikan III. Balai Penelitian Pemulihan dan Konservasi Sumber Daya Ikan.

Simanjuntak M. 2009. Hubungan Faktor Kimia, Fisika Terhadap Distribusi Plankton di Peraran Balitung Timur Bangka Belitung. Jurnal Perikanan Vol. 11(1): 31-45. Pusat Penelitian Oceanografi LIPI.

Subiyanto, Ruswahyuni dan Dwi GC. 2008. Komposisi Dan Distribusi Larva Ikan Pelagis Di Estuaria Pelawangan Timur, Segara Anakan, Cilacap. Jurnal Saintek Perikanan Vol. 4(1): 62 - 68 . Universitas Diponegoro. Semarang.

Suyasa IN. 2003. Pengelolaan Sumberdaya Ikan Indonesia (Pendekata Normatif).Makalah Falsafah Sains (PPs 702), Program Pasca Sarjana, Institut Pertanian Bogor.

Widodo J dan Nurhakim. 2002. Konsep Pengelolaan Sumberdaya Perikanan. Sekolah Tinggi Perikanan. Jakarta.

Wulandari Y. 2012. Status Perairan Banjir Kanal Timur Semarang Ditinjau dari Kadar Logam Berat Chromium dalam Air, Sedimen, dan Jaringan Lunak Kerang Darag (Anadara granosaa). Buletin Oceanografi marina vol. 1: 1-7. Universitas Diponegoro. Semarang. 